\title{
自動運転が引き起こす保険業界の変貌と その対応
}

——共通論題に扔ける論点の整理を中心にして—

\section{石田成 則}

\section{ロアブストラクト}

自動運転技術は，わが国の戦略的イノベーションの主柱となっている。こ うした技術の社会的な便益は大きいものの, 従来とは自動車の運行・走行概 念が大きく異なるため, それに見合うハード面とソフト面に跨る環境の整備 が必要になる。こうした環境整備が技術進展やその実用に追いつかないと， 社会的な軋轢を生じ，新技術への社会受容性は高まらないことになる。

こうした社会受容性を高めるために，自動運転に伴うリスクへの対処，事 故発生時の責任と補償のあり方，そして技術だけでは対応できない問題（ト ランス・サイエンス問題）への解決策を検討した。

結論として，事故発生時の補償については，従来の自動車損害賠償保障制 度を活かしつつ，民間保険商品によってそれを補完すべきことを主張した。 また，トランス・サイエンス問題への解決には, テクノロジーアセスメント に基づいた「コンセンサス会議」の実施により，一般市民の参画性と納得性 を高めることを提起した。併せて，民間保険商品の補償内容を工夫すること で技術選別を行うことの有用性を指摘した。

\section{ロキーワード}

テクノロジーアセスメント, トランス・サイエンス問題, 社会受容性

*平成29年10月29日の日本保険学会大会（滋賀大学）報告による。

/平成30年 4 月 10 日原稿受領。 


\section{1. 共通論題の目的}

内閣府が主導する SIP（戦略的イノベーション創造プログラム）自動走行 システム開発計画においては, (1)交通事故の低減, (2)渋滞の解消や運転者の 負担軽減，(3)次世代交通システムの実用化，などの目標が掲げられている ${ }^{1)}$ 。 具体的には, 大都市を中心とした交通渋滞や交通事故の抑止, 長時間運転に 伴う運転者・運転供用者の負担軽減が目標になる。現在でも自動車メーカー による運転アシスト機能により安全性は向上しており, 自動車事故件数自体 は年々減少傾向にある。ただし，若年ドライバーによる危険走行，煽り運転， 高齢ドライバーによる逆走や暴走事故などは続発しており，自動運転車の普 及促進は悪意やヒューマン・エラーによる事件や事故の抑制につながること も期待されている。渋滞や長時間運転がこうした事件・事故を引き起こす遠 因となるのであれば，その効果は一層大きいものとなる。

また，自動運転が実現することで，地方や過疎地域での交通弱者に対して， 移動手段を提供することができる。とくに，加齡に伴って生じる認知症や視 覚・聴覚に障がいを有するドライバーへの大きな手助けになる。自動車の運 転を制限されることなく，買い物やレジャーに勤しむことになれば，何らか の障がいがあっても，な扮生活空間が広がりアクティブに過ごすことができ る。完全自動運行が可能となれば，移動中の活動の自由度が広がり，その時 間を有効活用することが叶う。

このように自動運転は交通事故抑止や渋滞緩和などに大きく貢献する技術 であるものの，高いレベルの自動運転の実現には未だ課題が多い。あらゆる 天候や路面状況に技術的に対処することは難しく, 万一の事態へのシステム 上の対応に課題を残している。また一方で，自動運転車の事故では責任関係 が複雑化，輻輳化することになる。高度な情報通信技術を活用していても，

1）高度情報通信ネットワーク社会推進戦略本部（2017），19-20頁を参照のこと。 なお，自動運転の社会的価値については，日立製作所（2017）に詳しく整理さ れている。 
ハッキングや交通テロの危険性を完全に排除することは不可能である。それ だけに，自動車メーカーや関連企業に課される安全性基準は当然高いものに なる。しかし, 安全性確保のために必要以上の規制が掛けられることや，国 際標準から乘離することになれば，新たな技術開発への支障となり，その技 術が持つ可能性と効用を大きく減殺することになりかねない。そこで，こう した産業革命的な新技術のリスクをコントロールしつつ社会インフラも変革 し，社会的利益を最大化するように誘導することは喫緊の課題である。

共通論題では，まず，マスコミや情報誌に登場する過大な期待・夢物語や 逆に過度な懸念を排し，現在の自動運転技術のありのままの状況を把握する。 とくに，自動運転技術のコアである認知（センシング技術）, 判断（人工知 能技術）に加え，社会の新たなインフラとなる 3 次元地図システム（ダイナ ミックマップ）についてわかりやすく解説する。こうした現状把握を踏まえ て，今後の検討課題を掲げ各パネラーの報告内容に沿ってその解決策を模索 していく。

（1）自動走行に関する安全と安心の基準をどのように設定し，新技術から 生じるべネフィットとコストのバランスをどうとるのか?

(2) 自動運転車とダイナミックマップが生み出す大量のビッグデータの活 用，たとえば事故防止システムの開発など自動運転に伴う付加価值の可 能性について検討する。

（3）自動走行技術による自動車損害賠償保障法（自賠法）への影響と，自 動走行の実現に向けた自動車保険，製造物責任保険などの新たな保険商 品化の課題と展望について検討する。

（4）新技術に追いついていない法制度（自賠法，保険法，個人情報保護法 など）があるとすれば，それにどう対応すべきかを検討する。

\section{2. 自動走行システムとその技術}

自動車業界における近年の技術革新は目覚ましい。とくに, 地球環境への 負荷を抑制するために，ハイブリット車や EV 車が開発され市場を席巻しつ 
自動運転が引き起こす保険業界の変貌とその対応

つある。また，運転者・運行供用者の安全を守るために様々な技術が開発さ れ，交通事故の抑止に貢献している。こうした中で, AI (Artificial Intelligence）の技術を活かして「走るロボット」とも称される自動運転車の開発 にも拍車がかかり，その実現に向けた技術進歩が急展開している。衝突回避 のためのシステムや路上の障害物の認知，走行レーンの維持や先行車への追 随走行（ACC；Adaptive Cruise Control）などの新技術が続出している。こ れに合わせて，先進諸国は挙って国策として公道実証実験を行い，自動運転 車に適合する路上・路肩環境を急ピッチで整備している。

こうした新技術を順次搭載することで，段階的に完全自動化が進められて いる。運転には加速，操舵，運転制御の各過程があり，そのひとつが自動化 されている場合はレベル 1 ，複数が自動化されている場合はレベル 2 と称さ れる。これら全てを自動化する一方で, 緊急時などの必要最小限の操作を運 転者に託すケースはレベル 3 に分類される。こうした関与もなく，全て自動 化されている段階はレベル 4 にあたる。レベル 1 では安全な走行を技術が限 定的にアシストする。一方, レベル 2 や 3 では先進的な機器・装置と人間で ある運転者が共同で運行しているイメージがあるので準自動走行と把握され る。レベル 4 は完全自動化が実現している状況である $(\text { 表 } 1)^{2)}$ 。

\section{表 1 自動運転のレベルとその内容}

\begin{tabular}{|c|c|}
\hline システム名称 & 具 体 的 状 況 \\
\hline $\begin{array}{l}\text { 準自動パイロット } \\
\text { (レベル } 2 \cdot 3 \text { に相当) }\end{array}$ & $\begin{array}{l}\text { ・高速道路を中心とした自動走行モード } \\
\text { ・走行状況中にシステムからの通知機能の存在 } \\
\text { ・危機対応も含めた運転者・運行供用者の責任 }\end{array}$ \\
\hline $\begin{array}{l}\text { 完全自動パイロット } \\
\text { (レベル } 4 \text { に相当) }\end{array}$ & $\begin{array}{l}\text { - 高速道路, 一般道路の双方において自動走行モード } \\
\text { - 原則, あらゆる状況でシステム責任 }\end{array}$ \\
\hline 無人自動走行移動サービス & $\begin{array}{l}\text { ・遠隔運転者による自動走行システム } \\
\text { ・専用空間における無人自動走行システム }\end{array}$ \\
\hline
\end{tabular}

出所）高度情報通信ネットワーク社会推進戦略本部（2017），8 頁を参考に筆者作成。

2）なお，SAE Internationalによる自動運転レベルの最新の定義は，高度情報 
自動運転では様々な革新的技術が活用される。自動運転の形態・種別とし ては，誘導ケーブルや磁気マーカーを用いる路車協調型，隊列走行のような 車車協調型，そして周辺環境を察知するセンサー技術を活用した自律型や モバイル型があり，現在は自律型・モバイル型の開発が主流となっている (表 2 )。自律型の自動走行では，(1)自動位置認識技術（認知 1)，(2)外界認 識技術（認知 2)，(3)行動計画（判断），そして(4)車両制御システム（操作） が活用されている

\section{表 2 自動運転の形態・種別}

\begin{tabular}{|c|c|}
\hline 情報収集技術の種類 & 技術内容·情報収集手段 \\
\hline 自律型 & $\begin{array}{l}\text { 自動車に設置, 内蔵したレーダーやカメラを通じて障害物など } \\
\text { の情報を認識 }\end{array}$ \\
\hline モバイル型 & $\begin{array}{l}\text { GPS を通じた位置情報の収集 } \\
\text { ネットワーク網を通じてクラウド上にある地図情報などを収集 } \\
\text { ダイナミックマップなどの活用 }\end{array}$ \\
\hline $\begin{array}{l}\text { 路車間通信型· } \\
\text { 路車協調型 }\end{array}$ & $\begin{array}{l}\text { 路肩・路上インフラに設置された機器·装置などとの通信によ } \\
\text { り, 道路交通などの周辺情報を収集 }\end{array}$ \\
\hline $\begin{array}{l}\text { 車車間通信型· } \\
\text { 車車協調型 }\end{array}$ & $\begin{array}{l}\text { 他の自動車に設置された機器・装置などとの通信により, 各自 } \\
\text { 動車の位置や速度, 運転状況などを収集 }\end{array}$ \\
\hline
\end{tabular}

出所）表 1 に同じ，16頁。

自動位置認識技術とは，目的地までのルート上で，自車がどこに位置して いるかを確認するマクロ的な技術のことである4)。従来から GPS なとを活用 したシステムが用いられていたが，現在は 3 次元地図であるダイナミックマ ップと組み合わせる方法が一般化している。こうした地図には，道路形状， 交差点，標識そして勾配などの情報が含まれ，GPS を補いながら，その精 度を高めることに寄与している。

通信ネットワーク社会推進戦略本部（2017），5頁に整理されている。

3）須田・青木（2015），816頁を参照のこと。

4）ここでの説明は，横山（2015），19-21頁を纏めたものである。 
自動運転が引き起こす保険業界の変貌とその対応

外界認識技術とは，自動車に搭載された測定器である各種のセンサー（ミ リ波レーダー、レーザーレダーなど）を活用して，自車の周囲360度を認識 するものである。先行車の存在とその距離・走行速度, 道路標識・信号・交 差点，そして障害物や工事区間の存在について幅広く認識する。この技術に は，カメラによる検知とその画像処理を組合せた方式と，ミリ波レーダーに よる検知と物標同定技術を組合せた方式のふたつがある。両方式には一長一 短がある。前者では，十分な照明や見通しが確保されている限り障害物の存 在などに十分な効力を発揮するものの, 豪雨であったり逆光の場合では認識 精度が劣ることになる。逆に後者は環境変化にも頑強である反面，障害物の 認識に正確性を欠くきらいがある。こうした難点の克服が, 自動走行のひと つの課題になっている。

最後の行動計画とは，これまで運転者に任されていた「判断」の領域を自 動化するものである。こうした計画には「手順生成」「行動選択」「目標軌道 生成」「運動制御」のプロセスがあり，「行動選択」に $\mathrm{AI}$ などのロボット技 術が適用されている5 識情報をインプットして，自車の走行ラインや速度などを時系列に組み立て ることをアウトプットとしている。このアウトプットが, 車両制御システム に伝達されることで，ハンドルによる横方向制御とアクセル・ブレーキによ る縦方向制御が行われ，自動走行が実現する。「手順生成」「目標軌道生成」 「運動制御」の技術は従来型のカーナビゲーションなどでも可能であった。 そのため, ロボット技術を適用した「行動選択」が, 自動走行の頭脳を構成 する中核的・先進的技術となる。

なお，完全な自動走行が実現する以前では，自動車と運転者のインターフ エイス関連の技術も重要になってくる。運転の開始や終了については主に運 転者が主導するものの, 緊急対応時における自動走行システムから運転者へ のスイッチでは, その情報伝達の仕方が問われる。こうした移行がスムーズ

5）横山（2015），21-22頁，および，加藤（2015），42頁を参照のこと。 
にいかないと重大事故を招来しかねないのである。たとえば，レベル 3 の段 階でシステムによる運転が不可能となった場合には，運転者に TOR（Take Over Request）を提示して，運転を代わることになる。しかし，長時間に 渡ってシステムに運転を任せた場合，その代替に手間取ることが事故を誘発 しかねない。そのため, こうした際のヒューマンインターフェイスのあり方 について，自動停止のサブシステムやそのための空間確保などに技術的な問 題が残ることになる。

\section{3．自動車事故の責任と運行権限の分担}

自動運転では，各種の運転支援システムを組み合わせて，自動車事故を抑 止することを目指している。前方・後方安全機能や衝突被害軽減ブレーキな どによって，自動車事故を未然予防することになる。ただし，それでも事故 は避けて通ることができず，運転者・運行供用者以外に，自動運転を実現す るシステムが存在することから，新たにシステム責任の問題が生じてくる。 そのため, 事故発生時にはその責任関係が輻輳することになる。これに応じ て事故やトラブルを巡る訴訟リスクとその費用の増大も予期される。こうし た事態は，開発側のメーカーに対して費用増大となり開発意欲を萎ませると ともに，利用者側である一般市民や運転者・運転供用者の受容性をも減退さ せてしまう。

とくに前者について, 安全設計のためのフールプルーフやフェイルセーフ 設計のあり方が重要になるが, 多くのケースで,「安全性技術の程度と開発 費用」「安全性技術の程度と運転者の利便性」はトレードオフ関係に立つの でありその解決を迫られる ${ }^{6)}$ 。また，安全技術への誤解や誤認を生じさせな

6）海保・宮本 (2007)，59頁，66頁を参照のこと。「フールプルーフやフェイル セーフは，人間や機器がエラーを犯したときの対応をハード面に埋め込む設計 思想である。正しく機能しているうちは，安全なシステムと言える。しかしい くら安全なシステムでもユーザー側が設計の想定を超えて間違った使い方をし たり，安全性を過信したりすると新たな暴走が生まれる危険性がある。たとえ 
自動運転が引き起こす保険業界の変貌とその対応

いための詳細な運転マニュアルは，時に緊急時には運転者に混乱をきたすこ とがある。さらに，運転支援機能や自動化の程度が高いほど，ヒューマンイ ンターフェイスの高度化のために, 運転者の行動監視機能を強化しなければ ならない矛盾も孕んでいる。これらの課題に対して, 技術のみによって解決 策を得らえない点が最大の問題であり，後述するトランス・サイエンスの要 素を有するだけに厄介である。いずれにしても，自動運転には技術の高度化 による事故事例の複雑さや原因究明の困難さが付随するのであり，これらへ の適切な対処がなければ前に進めないことになる。

交通事故の責任には民事上の責任，刑事上の責任そして行政上の責任があ り，また事故の態様には人身事故・対人事故と物損事故・対物事故があるが, ここでは対人事故の民事責任に絞って話を進めよう。また，現在の道路交通 法や国際的な条約では, そもそも運転者・運行供用者の安全確認と操作が前 提になっているものの, ここではその前提を脇に置いて, 将来的な自動走行 の責任関係を整理してみたい。

自動走行の各段階において，「運転主体」「周辺監視」「運転バックアップ」 をだれが担うかがグラデーションのように変化する。現在も走行している一 部の運転アシスト車であれば，運転者がその全ての役割を担うことに変わり がない。しかし，レベル 2 の段階まで来ると，危機対応時の周辺監視や運転 のバックアップは依然として運転者に任されるものの，運転主体はシステム

ば車がさまざまなフールプルーフを搭載し安全性が増していくと, ユーザーは どんな場合にも安全だ誤解し，かえって安全軽視になってしまう。安全を重 視した設計は，使いやすさとトレードオフの関係にあることから，その設計を ユーザーが無視するケースもある。ㄱフールプルーフやフェイルセーフなどの エラー防止対策は，「人間は間違える」ことを前提に開発され，一定の成果を もたらしている。しかし時として人間は, 安全システムに目を背けた非合理な 行動をとることがある。運転中のカーナビゲーション使用などの違反行為もそ の一つである。非合理的な行動を抑制することも, 事故防止のための安全設計 思想に取り达んでいかなくてはならない」(67-69頁)。こうした目的のために, 一般市民の道徳観や倫理観を取り达んだ安全システムを提唱している。 
との共同責任といっていい状況になる。これがレベル 3 になれば，周辺監視 も含めてシステムに委託されるために，運転者の役割は一時的なバックアッ プなど限定的になる。完全な自動走行状態であれば，運転者が一切の責任を 負わないために，役割の分担関係は生じず，責任の所在も明快である。つま り，こうした状況に至る以前のレベル 2 やレベル 3 において，役割分担の境 界が不分明であることから，事故発生時にもその責任の所在が問題となるの である。

同時に，交通事故に至るリスクをどのように分担していくかが，被害者救 済のためにも，また技術革新のためにも非常に重要になってくる。自動走行 以前のレベル 1 の場合，運転者が走行の全てを制御下に置いている。そのた め, 各種のアシスト機能が緊急時に作動し運転行為を支援するとはいえ，た とえば衝突被害軽減ブレーキが作動するまでもなく，自ら緊急停止する責任 は一義的に運転者にある。レベル 2 になるとやや複雑であるものの，縦方向 の制御（定速走行・車間距離制御装置など）と横方向の制御（横滑り防止装 置など）をシステムが行うとはいえ, 周辺監視も含めて運転者に全般的な対 応が求められることから，責任関係はレベル 1 と大差がないと思われる。こ の際に問題になるとすれば，運転者がどの程度，システムの機能限界やシス テムの自動作動に関する判断根拠を認識しておくべきかである7)。これには, 自動走行のシステムを理解するための教習・教育制度などがかかわってこよ う。前述の外界認識技術にも限界があり，障害物が存在することで誤作動が 生じた場合，どこまで運転者に責任を求めるかも問題となる。

これがレベル 3 になると状況が異なり，自動制御だけでなく周辺監視の役 割も担うだけに，自動走行システムの責任は格段に重くなる。一方，危機対 応時には運転者に突然，運転バックアップの役割が移譲されるため，事故発 生時の責任のあり方は輻輳する。そのため, 役割の移譲を段階的にすること や，移讓された運転者に判断の猶予を与えるなどの工夫が必要になる。こう

7）稲垣（2015），52頁を参照のこと。 
自動運転が引き起こす保険業界の変貌とその対応

した工夫のあり方と，その内容を的確に伝達しているか否かで，責任分担の あり方が変わることになる。多くの場合，「一定条件下での安全運行の保証」 と「緊急時における運転者への権限切替え」がセットになると考えられ，自 動車メーカーは「一定条件下」と「緊急時」とをわかり易く記述し説明する 義務があり，この義務の履行が責任の判断基準になろう。

こうした役割の移譲や分担を決める主体も重要になってくる。たとえば, 自動走行を止めて運転者がハンドル操作を楽しみたい場合には，決定主体は 運転者自身である。これに対して，衝突被害軽減ブレーキはシステムが主体 となって，運転者からシステムへの切替えを要請する。それが上手く作動せ ずに事故が発生すれば当然，システムの責任になる。同様にして車線維持支 援制御装置では，その機能をシステムが自動的に解除することがある。その 後，運転者が上手く車線変更ができずに事故が発生したとしても，運転者の 責任とはいいがたい。システムの切り替えを要請した主体であるシステム自 身の責任が問われることになる。緊急停止であっても，その場に急停車する ことは後続車との衝突などの事故を招くほか, 運転者の飛び出し行為などで 事故を誘発しかねない。安全に路肩誘導して停車する技術以外では，何らか のシステム責任が発生する危険性がある。

基本的な責任関係はこのように整理できるものの，そのあり方は賠償問題 を超えた広がりをもっている。まず本来, 自動走行における運転者・運行供 用者の注意水準は低くていいはずなのに，かえって高い水準が要求される可 能性も指摘されている。こうした高い注意水準が求められると, 需要者が限 定され自動運転車への需要減の危険を孕むことになる。また，ある程度のシ ステム切替えリスクや，ハグのリスクを容認していかないと自動運転車開発 へのブレーキになりかねない。こうしたことから，技術的観点からの責任分 担のあり方に捉われることなく，自動走行の効果・効用などの派生的な影響 も考慮に入れることが肝要になる。

なお，ここでは外部からのシステムのハッキング・リスクは明示的に取り 上げないものの, その対処には個別企業を超えた全社的対応や行政による対 
応を要している。また, 運転者・運行供用者以外の責任をシステム責任とし たが, 個別事例では事故形態や事故類型に応じて, メーカーや販売店そして ソフトウェア会社の責任分担もポイントとなる。とくに，完成品としての自 動運転車に含まれるシステムやプログラムによる事故について，その責任を 全てメーカーに求めると, 開発主体であるメーカーの革新的行動が委縮しか ねない。ここでも，派生的な影響に配慮することで，責任分担のあり方を決 める発想が要る。両取引者間で明示的な契約関係を確立し, 自動車メーカー の不法行為責任，システム開発者の製造物責任そしてソフトウェア会社の債 務不履行責任を明確にすべきである。

\section{4. 事故時における補償システムのあり方}

これまで人身事故を中心として，わが国の自動車損害賠償保障法（通称， 自賠法）が被害者救済に大きな役割を果たしてきた。とくに，事実上の無過 失責任主義によって迅速な被害者救済を実現してきた。運行供用者が責任を 問われないためには，自己（自らが運転者の場合）および運転者（自らが運 転者でない場合）が自動車の運行に関し注意を意っていないこと，被害者ま たは運転者以外の第三者の故意または過失があったこと, そして自動車に構 造上の欠陥や機能障害がないこと，以上の 3 要件を自ら立証する必要があっ た。第一要件にある注意水準には，安全な走行に必要な注意義務だけでなく， 自動車の点検整備に関する注意義務もある。また，ここでの過失には事故な どの「予見可能性」とその「結果回避義務」のあり方が関わってくる。

現在，自動運転による自賠法の枠組みへの影響については，免責 3 要件と 関連して様々な議論がある。今後も完全自動走行に移行する過程と, 自動運 転の各レベルにおいて，議論を詰める必要がある ${ }^{8)}$ 。

8）実はこうした問題は既に，山下（2005），138頁によって指摘されている。自 動車に構造上の欠陥や機能障害がないことに関して, 裁判事例などで被害者救 済を重視するあまり，運行供用者が被害者に一旦責任を負ったうえで，その後 にメーカーや関連会社に求償するやり方は実効性が低い点を指摘する。この状 
自動運転が引き起こす保険業界の変貌とその対応

完全自動走行以前では, 従来の自賠法の枠組みを維持することが可能であ るとの見解が多い。その場合でも，運行供用者概念の適用可能性や自賠法上 の免責 3 要件の妥当可能性について検討が必要である。とくに, 事故時の運 転支援装置の故障の場合，こうした装置の点検整備や内包されるシステムの アップデート，ソフトの更新について，どのような注意水準が求められるか がカギとなってくる。また，自賠法の枠組みを維持するとして，事故が自動 運転車や付随している各種のシステムによる場合，欠陥商品としてどこに賠 償責任を請求するのか, システムやソフトの販売店やソフトウェア会社の説 明義務をどのように設定するのかが，問われることになる。

たとえば，運転支援装置のひとつである衝突被害軽減ブレーキにしても， これが明らかに誤作動して事故に至ればシステム設計者, ソフト作成者の責 任は免れず，製造物賠償責任を問うことができよう。しかしながら，緊急時 にそれが発動しなかったとしても，本来的なブレーキが備わっているのであ り，製造物責任がある，ないしは不法行為責任があるとまでいえないことに なる9)。それにより事故が招来された場合，自動走行中であればシステム責 任は大きいものの，運転者による走行であればシステム責任を問うことはや や難しくなる ${ }^{10)}$ 。これが濃霧などの外界環境に起因する場合, メーカー側が 外界認識技術の限界について事前に説明を尽くしているのであれば，責任を 免れることになろう。このケースでも，運転者が「周辺監視」を担っている のであれば話は簡単だが，システム側が担っている場合，限界を超えた状況 に至っていることを運転者に伝える責任が生じる。そのためインターフェイ スの適切性が問われることになる。それが不適切であれば，表示・警告上の 欠陥が指摘されることになる。併せて, 自動走行中であれば外界認識技術の

況は自動運転によって悪化し，保険会社による求償も現実的でないとすれば, 事故費用の内部化作用が働かず，メーカーによる安全投資が後退することを危 惧している。

9）藤田 (2017), 26頁。

10）窪田（2017）, 34頁。 
限界に対する冗長性の確保として，サブシステムを具備しているかも問われ る危険性がある。

これに対して，高度な，または完全な自動運転車は走るロボットであり， 自賠責の枠組みに当てはまらずに，ロボット賠償責任保険などを新設するこ とで，結果的に被害者救済を果たすべきであるとの見解もある。また，賠償 義務者の存在を前提とする現行の制度は, 被害者救済に必ずしも適している わけではないとの主張もある。そこでは新たな被害者救済の仕組みを論議す る必要が生じてくる ${ }^{11}$ 。こうした論議の延長線上には, 国の上積み保障とし て，民間任意保険の商品開発を促し，官民で補償を強化することも考えられ る。

このように，事故の形態も責任分担のあり方も自動運転の進展度合いによ って異なってくる。また，民の技術革新だけでなく，国や自治体によるイン フラ整備もかかわっている。都市部の狭い路地や急角度の交差点などは自動 走行の支障になる危険性が高い。車線を仕切る白線が不鮮明であったり，緊 急停止区域の表示が不明瞭であっても事故は誘発される。また，一部で路車 協調型の自動走行が進展する場合や，自動走行車のシステム監視を官が担う

11）今井（2015），61頁に打いて「自動化運転に係る交通事故の法的責任如何は, 技術提供者としてのメーカー（製造者）の責任として, 先鋭化する。日本の法 制度の下では，広義の製造物責任の中で，民事のそれしか，実定法化されてい ない。製造物責任法によれば，自動化運転に供された技術に不備があった場合， 当該技術を提供したメーカーには無過失責任が生じうる。しかし, 当該技術の 基礎となるプログラム上の不備は，製造物責任の対象外である。」製造物の法 的責任は，本来は，事故の原因につき，少なくとも過失が認められる場合にし か是認されない。製造物責任法は, 被害者救済のために, この原則の例外とし て，無過失責任を認めているが，こうした例外が許容されるのは，被害者救済 の必要性ないし製造者の過失立証が事実上不可能に近い場合に限られる。そし て，プログラムが，その設計者の意図に反した誤作動をする可能性を遍く排除 することはできないから, メーカーに, 当該誤作動に起因する交通事故に係る 法的責任を全て負担させることは, 衡平でないと言えよう。…現行の製造物責 任法の趣旨を踏まえると, 同法にいう「製造物」に，自動化運転に係るプログ ラムを含めるという法改正が，早急に検討されるべきであろう」(61-62頁)。 
自動運転が引き起こす保険業界の変貌とその対応

場合にも，それに合わせた環境を整備すべきである。こうしたハード面に加 えて, ソフト面の法律や制度についても変革が必要であり, それによって自 動走行システムの社会受容性が影響を受けることになる。技術革新に追いつ いていないハードとソフトの社会的制度や仕組みがあるとすれば，それがネ ックとならないような環境作りが大切になる。

自動走行車は走るロボット, 自ら学習するロボットであるとともに, 夢の ような「どこでもドア」でもある。こうした状況では, 自動車の保有自体意 味を持たなくなる社会, カーシェアリングが一般化し全てが疑似公共交通と なる社会も現実味を帯びてくる。過踈地での交通利便性向上，高齢者や障が い者の交通手段確保，そして災害救助への活用などによって「つながる社 会」を実現することにもなる。移動地域のバリアフリーは，精神面でのバリ アフリーにもつながり，高齢者や障がい者の生き甲斐を生む。自動走行技術 は社会経済の様々な場面に影響を及ぼすことになる。そこで, 自動運転の技 術革新による社会経済へのインパクトについて議論を深めること，別言すれ ばテクノロジーアセスメントが一層重要になる（表 3 )。

\section{表 3 自動走行技術の社会的インパクト}

\begin{tabular}{|c|c|}
\hline 基本的な目的 & 期待される効果 \\
\hline $\begin{array}{l}\text { 自動走行システムの社会的 } \\
\text { 利益の認識と更なるイノべ } \\
\text { ーションへの期待 }\end{array}$ & $\begin{array}{l}\text { ・交通事故削減, 渋滞の解消，そして省エネルギーをはじ } \\
\text { めとした自動車の社会的費用の軽減 } \\
\text { ・新技術・新産業の創出，ITS・インフラへの貢献 } \\
\text { ・新たな融合技術への期待，災害時救助・医療への援用 }\end{array}$ \\
\hline $\begin{array}{l}\text { 自動走行システム導入に伴 } \\
\text { うリスクの軽減 }\end{array}$ & $\begin{array}{l}\text { ・自動走行システムによる安全性向上の支援 } \\
\text { ・従来型の強制保険（自賠責保険）と民間保険による対応 } \\
\text { ・テクノロジーアセスメンントの進展 }\end{array}$ \\
\hline $\begin{array}{l}\text { 自動走行システムを通じた } \\
\text { 市民生活・地域社会の変化 }\end{array}$ & $\begin{array}{l}\text { ・移動時間中の自由度の拡大による新たな消費活動 } \\
\text { ・交通渋滞の解消による移動に伴うストレスの軽減 } \\
\text { ・運送業や配送業における人手不足の解消 } \\
\text { ・高齢者や障がい者の行動範囲の変化など生き甲斐の創出 }\end{array}$ \\
\hline
\end{tabular}

出所）表 1 に同じ，22頁。なお，筆者が一部加筆修正している。 


\section{5. 自動運転の社会受容性向上のために；トランス・サイエンス問題 の解決}

リスクマネジメントの理論に予期図式という概念がある ${ }^{12)}$ 。危険を予知す る際に，過去の危険体験の結果として，眼前の危険を察知してそれに対処す るための構造化された知識を指す。これが危険回避行動を促すことになる。 しかし，予期図式は教えられて身に付く知識でないことが指摘されている。 それは長年の勘であったり，現場力であったりする。自動運転車について， こうした勘が働かないとすると, 危険回避も困難になる。そこで, 文章化さ れた予備知識と体感が異なることを前提に, 自動運転の運行のために新たな 講習が要ることになる。運転アシストや自動運行に対する依存心が強ければ 強いほど, こうした講習の重要度は高まるとともに, 継続的な「学習」も不 可避であろう ${ }^{13)}$ 。

ただしこうした講習会や学習機会では, 自動運転の事故回避のために, 自 動運行のシステムそのものへの理解も欠かせない。そのため, 単に講師側や 講義の提供側が教え込むのではなく，素人目線の質問などを共有しながら， 共通の基盤に立って進めていくことが望まれる。とくに，自動車事故という リスクに関わる問題であるために，リスクの計量化やリスクに対する複眼的 な思考も必要になるものの, システムに疎い素人は全てを理解しがたい。正 に，自動運転システムのあり方を挟んで，専門家と素人が対峙する構困であ り，トランス・サイエンス問題が発生していることになる。ここで, トラン ス・サイエンスとは,「科学によって問うことはできる（技術的には解決可 能である）が, 科学によって答えることができない問題群からなる領域」と 定義されている ${ }^{14)}$ 。原子力発電や遺伝子検査・遺伝子組み換えなどを通じて

12）海保・宮本 (2007)，23頁。

13）こうした依存心から, システムに対する過信や著しい注意力の低下が生じゃ すい。

14）小林 (2007), 123頁。 
自動運転が引き起こす保険業界の変貌とその対応

生じている問題がここでも顕在化することになり，それが自動運転への社会 受容性を決定する大きな要因ともなりうるであろう。「故障や事故の起こる 可能性がきわめて低い確率であるとしたとき，それを無視できる確率とみな すのか，それとも万が一それが起こった場合の災厄の大きさを考えると無視 できないと考えるのか，これは科学が答えを出すことはできない」とされ るのである。そして重要なことは，「技術が社会の仕組みの表現」であるこ とである ${ }^{16)}$ ○「社会に実装される技術は決して中立的なものではなく，その 社会の価值観，意思決定の仕組みの表現」であるとして，たとえば，原子炉 の安全装置や遺伝子組み換え食品への規制の程度は各国の価值観や, 社会的 な意思決定の仕組みを反映することになると指摘する。

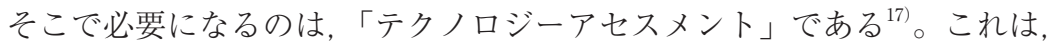

15）小林 (2007), 124頁。

16）小林 (2007), 129頁。

17）小林 (2007)，182-185頁を参照のこと。残念なことに，わが国では公害問題 が顕在化した1960年代70年代に一時隆盛をみたものの, その後はこうした考え 方が根付かず，技術先行になっている点が指摘される。城山・吉澤・松尾・畑 中 (2010)，200頁によれば，1971年当時に科学技術庁計画局が農薬に関する事 例研究を分析するなど, 先行的な事例は過去に見受けられるとしている。当時 の TA 総合検討会農薬分科会では, 米国マイター社の TA 手法を活用した考 察が行われたとしている。こうした手法は, 自動運転の技術にも活用できると 思われる。1）第 1 段階; 対象技術の範囲と目的の明確化, 2 ）第 2 段階; 対 象技術及び関連技術の詳細な認識，3）第 3 段階；技術が社会に及ぼす影響の 列挙，4）第 4 段階；技術の社会への影響の実態把握，5）第 5 段階；個々の 影響の第 1 次評価，6）第 6 段階；負の影響に対する対応策の列挙とその効果 の把握， 7 ）第 7 段階; 最終評価。この最終評価では, 全てのステークホルダ 一に対する影響の評価を行っている点に特色がみられる。一方，吉澤（2009） ではテクノロジーアセスメントを「先進技術に対し，その技術発展の早い段階 で将来のさまざまな社会的影響を予期することで，技術と社会のあり方につい ての問題提起や意思決定を支援する制度や活動」（42頁）と定義したうえで, 欧米における実践では，幅広い関係者や国民一般を巻き込み，それぞれにとっ ての便益や, 安全やリスクに対する考え方の違いを認識し, 対話を図りながら 科学技術の発展の方向性を舵取りしているとする。そして, 技術を社会におけ 
「科学技術の発展が社会にもたらしている，あるいは将来もたらすと予想さ れる影響を，分析評価し，国の政策に反映させる」（182頁）という考え方で ある。とくに，米国では「科学技術がもたらす利益だけではなく，それがも つている危険性に着目し，同時に科学技術の性格を国民に知らせる必要性が ある」(182頁) とされている。欧米諸国ではテクノロジーアセスメントを積 極化することで技術の社会受容性を高めてきたが，現在ではその限界も指摘 されている。それは正に，トランス・サイエンス問題であり，正しい科学知 識の理解とその活用法を知ってもらうだけでは, つまり科学技術が科学技術 としてあるだけでは，社会受容性の向上に限界があることである ${ }^{18)}$ ○こで は，科学技術を活用する一般市民こそが，様々な側面をもつ実社会生活にお ける科学技術の評価主体であるべきと考える。そのために，技術の専門的な 安全性や効率性などの評価に加えて, 倫理的視点, 社会経済的な視点も加味 することが望まれる。専門家が視野狭窄に陥りやすいのに対して，一般市民 はそのバックグラウンドに応じて，多様な幅広い視点を有していることが一 般的である。同時に，従来から技術導入後の評価が通例であったのに対して， 社会受容性のために事前評価も求められ，そのことが節度ある技術開発を促 すことにもなる。

こうした考え方のもとで，欧米諸国では，専門家である科学者・技術者と 一般市民が共通の土俵で，同じ目線に立つて議論する科学技術に関するコン

るトータルシステムと捉え, その全体像を「予測」「評価」そして「コントロ ール」することの重要性を説く（43頁）。併せて，国家技術戦略を「戦略的」 なものとするためにも不可欠であるとしている。

18）山口（2016）, 146頁において「イノベーションは，科学と社会との関係の中 で生み出される一つの創造行為である。それを科学と社会の第一の関係性とす るならば, 科学と社会の第二の関係性が存在する。…すおち, 科学が引き起 こしながらも社会が参加しなくては解決できない「トランス・サイエンス」の 問題である。その多くは，科学が社会を損なうような問題である。」また，148 頁において「トランス・サイエンスとは, 多数決原理が意味を持ちえない科学 と，多数決原理によって前進していく民主社会が同居する自己矛盾をはらんだ 概念にほかならない。」 
自動運転が引き起こす保険業界の変貌とその対応

センサス会議が実行されている ${ }^{19)}$ 。今後, 自動運転の開発から公道実験に至 る過程で，様々な事故やトラブルが発生することが予想され，またそうした 事態は完全自動運転車が走行するようになっても続くものと考えられる。こ うした事態に過剰反応を引き起こすことなく, 社会受容性を継続的に向上さ せるには，コンセンサス会議に類する市民会議を実施していくべきである。 こうした会議を通じて, 自動運転という社会的投資の意義を共有する場を構 築していくことが大切である。

またいくつかの研究から，前述した運転アシストや自動運行への依存心は， 危険回避能力を著しく低下させることも明らかになっている。こうした状態 にあっても，事故発生時に過失があれば，当然のことながら運転者・運転供 用者の責任が問われてくる。理論的にはそれで正しいであろうが，システム に疎い素人ドライバーには俄かに受け入れがたい側面もある。これなどもト ランス・サイエンス問題であり, 単にフェイルセーフの仕組みを組み込むだ けでなく，素人感覚を技術面の工夫に反映させる必要がある。

自動運転では，一般ドライバーだけでなくテストドライバーですら機械へ の依存を生んでしまう。素人であれば猶更である。それが過信や過誤につな がる。さらに, 複雑な条件や操作になると, 合理的な機械とは異なる非合理 な人間は様々な誤操作をしてしまう。こうした点を踏まえて, 非合理な行動 をとるドライバーによる試運転も必要といえる。これが非現実であれば, $\mathrm{PC}$ 上のシミュレーション実験を繰り返すしかないものの, それと実際の運 行とは異なることにも留意が必要である。緊急時に対応が必要なケースでも， 完全自動走行で欠陥があるケースでも，最終的にはドライバーも含めて自動 車に同乗している人間の行動を通じて，またその心理的変化を通じて事故発 生の有無が決まる。このように, 素人判断や素人行動を反映した安全運行の

19）コンセンサス会議の具体事例については，小林（2007），186-217頁を参照の こと。な㧍わが国でも，自動走行システムに関して「メディア・ミーティン グ」や「市民との直接対話方式の市民ダイアログ」が一部で開催されている （高度情報通信ネットワーク社会推進戦略本部（2017），46-47頁)。 
仕組みが求められることになり，これこそがトランス・サイエンス問題解決 の糸口といえる ${ }^{20)}$ 。そのうえで，機械と人間のインターフェイスのあり方次 第では，運転者・同乗者の利便性を犠牲にしても，安全性を確保することが 必要な場面も生じることになる。

また，個人差への対応も必須であり，個人のリスク感度などに応じた対応 が望ましい ${ }^{21)}$ 。時間選好率・危険回避度に応じた説明の工夫や，技術イノべ ーションや進取の気質に対応した講習内容の差別化によって, 理解を深める ことができる。さらに，事故形態や責任関係の複雑化や輻輳化は過剩反応や 委縮感情を引き起こしやすい。こうした問題への対処にも，ドライバーや同 乗者の行動変化の形態を明らかにする実験の有用性がある。一般市民をこう した議論に巻き込んで，参画性を高めていくことにより，自動運転の問題を 自分自身の問題として捉えることができ, 社会受容性を向上させることがで きる。

わが国の TAのなかで，医療の診療報酬制度における医療評価が中央社 会保険医療審議会により行われてきたが，これは他の TA とは趣を異にす る。それは, 新薬や新治療法などの新規技術を社会保険適用の有無から判断 するからである ${ }^{22)}$ 。その評価項目には, 有効性, 安全性, 普及性, 技術の成 熟度, 倫理的・社会的妥当性, 予想される医療費への影響, 他の技術との比 較考慮などが含まれ，それにより保険適用の範囲が決定される。所得分配の 側面がある社会保険と任意の民間保険を同列に論じることはできないが，自 動運転の諸技術や諸機能について TA を実施することで, 包括的な保険適

20）そこで，様々な条件設定を通じてドライバーや同乗者の行動が変化すること を，行動経済学の知見を活かして明示することも有用である。

21）山口（2016），60頁における社会受容性に関する態度の類型化を参照のこと。 とくに，社会的なイノベーションに対して批判的態度をとる人の中にも，安全 性を過度に心配するタイプ，新技術利用の公平や平等を重視する夕イプ，そし て導入期における専門家とのコミュニケーションを重視するタイプなど，様々 であることを指摘している。

22）城山・吉澤・松尾・畑中（2010），205頁。 
自動運転が引き起こす保険業界の変貌とその対応

用ではなく，選別的に普遍的かつ社会的妥当性が高いものを補償の対象とす ることもあり得る。それには，対物賠償を中心にその原因究明ができ，ドラ イバーとシステムの責任関係を明確化することが前提になる。このような選 別機能を通じて，民間保険が社会受容性向上に寄与することも考えられる。

(筆者は関西大学教授)

\section{<主要参考文献>}

池田裕輔 (2017)「自動運転技術等の現況」『ジュリスト』1501号。

稲垣敏之 (2015) 「自動運転における人と機械の協調」『国際交通安全学学会誌』40 巻 2 号。

今井猛嘉 $(2015) 「$ 自動化運転を巡る諸問題」『国際交通安全学学会誌』40巻 2 号。 大島道雄 (2015) 「自動運転と損害保険事業」『損害保険研究』77巻 1 号。 大谷孝一・中出哲・平澤敦編著 (2012) 『はじめて学ぶ損害保険』有斐閣。 大羽宏一(2017)「自動運転を巡る産業界の動向と今後の社会のあり方」『損害保険 研究』79巻 1 号。

岡本暁子・西村吉雄・若杉なおみ (2009) 『科学技術は社会とどう共生するか』東 京電機大学出版局。

海保博之·宮本聡介 (2007) 『安全·安心の心理学』新曜社。

加藤一郎・木宮高彦(1991) 『自動車事故の損害賠償と保険』有斐閣。

加藤晋 (2015)「走路環境認識と経路計画」『国際交通安全学学会誌』40巻 2 号。 窪田充見 (2017) 「自動運転と販売店・メーカーの責任」『ジュリスト』1501号。

高度情報通信ネットワーク社会推進戦略本部・官民データ活用推進戦略会議

（2017）『官民 ITS 構想・ロードマップ2017』（http://www.kantei.go.jp/jp/singi/it2/kettei/pdf/20170530/roadmap.pdf）最終閲覧日2017年11月30日。 国土交通省自動車局 (2018) 『自動運転における損害賠償責任に関する研究会報告

書』(http://www2.mlit.go.jp/common/001226364.pdf) 最終閲覧日2018年 3 月31日。 小林傳司 (2007) 『トランス・サイエンスの時代』NTT 出版。

経済産業省 (2017) 『自動走行の民事上の責任及び社会受容性に関する研究（スマ

ートモビリティシステム研究開発・実証事業有識者委員会委託事業報告書)』テ クノバ。

佐藤智昌 $(2015) 「 人 工$ 知能と法」『青山法学論集』57巻 3 号。

城山英明・吉澤剛・松尾真紀子・畑中綾子 (2010)「制度化なき活動一日本におけ

る TA（テクノロジーアセスメント）及び TA 的活動の限界と教訓」『社会技術 
研究論文集』 7 巻。

須田義大・青木啓二 $(2015) 「$ 自動運転技術の開発動向と技術課題」『情報管理』57 卷11号。

高橋郁夫・有本由真 $(2016) 「$ 自動車システムの法律問題一自動運転を中心に」『情 報ネットワーク・ローレビュー』14巻。

近内京太 $(2015) 「$ 自動運転自動車による交通事故の法的責任」『国際商事法務』44 巻10号。

戸嶋浩二 (2016)「自動走行車（自動運転）の実現に向けた法制度の現状と課題 (上) (下)」『NBL』1073号, 1074号。

中山幸二 (2016)「自動運転の進展と交通事故の賠償責任」『共済と保険』58巻 7 号。 日本能率協会総合研究所 (2016) 『自動走行の制度的課題等に関する調查研究報告 書』(https://www.npa.go.jp/koutsuu/kikaku/jidosoko/) 最終閲覧日2017年11月30 日。

芳賀繁 (2000) 『失敗のメカニズム』日本出版サービス。

日立製作所 (2017) 『平成28年度スマートモビリティシステム研究開発・実証事業 (自動運転による新たな社会的価值及びその導入シナリオの研究)』日本社会イ ノベーションセンター。

藤坦裕子・廣野喜幸編 (2008) 『科学コミュニケーション論』東京大学出版会。

藤田友敬 (2017) 「自動運転と運行供用者の責任」『ジュリス卜』1501号。

村田厚生 (2008) 『ヒューマン・エラーの科学』日刊工業新聞社。

柳川範之編 (2017) 『人工知能は日本経済を復活させるか』大和書房。

山口栄一(2016)『イノベーションはなぜ途絶えたか』ちくま新書。

山下友信編 (2005) 『高度道路交通システム（ITS）と法一法的責任と保険制度』有 斐閣。

横山利夫 (2015) 「自動運転の実像」『国際交通安全学学会誌』40巻 2 号。

吉澤剛 (2009)「日本に扔けるテクノロジーアセスメント一概念と歴史の再構築」

『社会技術研究論文集』 6 巻。 